\title{
Fetomaternal outcome in multiple pregnancy
}

\author{
Senthilpriya Sundaram, Keerthana Govindaraj*
}

Department of Obstetrics and Gynaecology, Vinayaka Mission Kirupananda Variyar Medical College and Hospital, Salem, Tamil Nadu, India

Received: 14 October 2021

Accepted: 29 October 2021

\section{*Correspondence:}

Dr. Keerthana Govindaraj, E-mail: keerthi2111@gmail.com

Copyright: (c) the author(s), publisher and licensee Medip Academy. This is an open-access article distributed under the terms of the Creative Commons Attribution Non-Commercial License, which permits unrestricted non-commercial use, distribution, and reproduction in any medium, provided the original work is properly cited.

\section{ABSTRACT}

Background: Multiple pregnancies are more common in recent days than in the past. Increased maternal age at conception due to delayed childbearing trend has resulted in multifetal gestations. Twin gestation imposes greater demand on the maternal physiological system than does singleton pregnancy. The incidence of multifetal gestation has increased mainly because of advanced maternal age and assisted reproductive technology. Multiple pregnancy is considered as high-risk pregnancy as it contributes significantly to adverse maternal and perinatal outcomes.

Methods: In this prospective observational study conducted in obstetrics and gynaecology department VMKVMCH, Salem for 6 months period, around 50 cases of multiple pregnancy were taken into consideration and patients were followed up from admission till delivery and neonatal outcome analysed. Main outcome measures were maternal complications (anaemia, pre-eclampsia, post-partum hemorrhage, gestational diabetes mellitus (GDM), perinatal mortality and morbidity.

Results: Higher incidence of twin gestation was noted between the age group of 20-25 years and maximum were of spontaneous conception. None of them had family history of twins or past history of the same. We noted that maximum were preterm deliveries and majority of the patients underwent lower segment caesarean section (LSCS). Twin specific complications were noted according to their chorionicity. Most of the babies weighed between 1.5-2.5 kg. Perinatal mortality was $7.5 \%$ and no maternal mortality noted.

Conclusions: The knowledge of maternal and fetal risks associated with multiple gestation helps in prevention of adverse outcome and better surveillance.

Keywords: Twin gestation, Maternal, Perinatal, Chorionicity

\section{INTRODUCTION}

Multiple pregnancy refers to a development of 2 or more fetuses simultaneously in a pregnant uterus. The naturally occurring twin pregnancy is approximately 1 in 80 births and natural higher order multifetal gestations are uncommon. The evolving infertility treatment has lowered the rate of higher order multifetal births. The incidence was $1 \%$ of all pregnancies but the incidence rate appears to be variable in different parts of the world. ${ }^{1-3}$ Multifetal gestations are more common in recent days than in the past and the incidence is largely fueled by the infertility therapy. The rates, number of twins and higher order multifetal gestation increased between 1980 and 2001. ${ }^{4}$
Prevalence of twin births varies between 2-20 per 1000 births throughout the world. The increase in multiple gestation can be due to women's attitude towards childbearing and postponing pregnancy in favour of career, work and also because of increased trend in seeking infertility treatment like assisted reproductive techniques (ART) and conception at advanced maternal age. ${ }^{5}$ One of the predisposing factor of twin gestation is increase in maternal age which leads to decrease in fertility and this may lead to increased use of ART like ovulation induction, in vitro fertilization and intracytoplasmic sperm injection. ${ }^{6,7}$ Multiple pregnancy imposes greater demand on the maternal physiological system than do singleton pregnancies. With increase in the incidence of twin 
pregnancies increase in the rate of maternal mortality were noted, thus it is a very challenging task for obstetrician. It is also associated with poor perinatal outcome. Complications occur in $25 \%$ of singleton pregnancies whereas $83 \%$ of twin pregnancies have complications leading to $10 \%$ perinatal mortality. ${ }^{8,9}$ Increased maternal complications are due to burden on the adaptive capacity, hence twin pregnancy is considered as high-risk pregnancy and needs vigilant obstetric care. ${ }^{10}$ There are 2 types of twin pregnancy: fraternal and identical. The cause for twining is not known, multiple pregnancies occur more frequently from fertilization of 2 separate oocytes (dizygotic) than from single fertilized oocyte which subsequently divides into two identical twins (monozygotic). Approximately $30 \%$ are monozygotic and $70 \%$ are dizygotic. Monozygotic twins occur at a rate of 1 in 250 births and is constant throughout the world. Twoto-five-fold increased incidence of monozygotic twins are due to conception by ART. Maternal factors like high parity, rising maternal age, races, hereditary factors (especially maternal side) lead to increased frequency of dizygotic twins. Chorionicity rather than zygosity is the main factor to determine the pregnancy outcome. ${ }^{3}$ Chorionicity is detected by ultrasonography in antenatal period and by placental examination following delivery. It is classified as monochorionic monoamniotic (MCMA), monochorionic diamniotic (MCDA) and dichorionic diamniotic (DCDA). The incidence of intrauterine death (IUD), fetal abnormalities, twin-twin transfusion syndrome (TTTS) is common in monochorionic twins and increasing development of discordant growth is seen in monochorionic twins, hence Monozygotic twins are at greater risk. ${ }^{3}$ Increased rate of maternal risks like antepartum haemorrhage, pre-eclampsia, anaemia, polyhydramnios, premature rupture of membranes (PROM), preterm labour and postpartum haemorrhage are noted in multifetal gestation. Because of the higher rate of complications, caesarean section rate also becomes higher in multiple pregnancy when compared with a singleton gestation. ${ }^{11,12}$ Fetal risks that are anticipated in multiple pregnancies are prematurity, fetal growth retardation, low birth weight, birth asphyxia, birth trauma, congenital anomalies and certain fetal complications peculiar to twin pregnancies. Twins have five-fold risk of dying before the age of one year when compared to singleton pregnancy. Failure rates are higher in normalising the complications in multiple pregnancy even with vast available and advanced knowledge. So, the idea of close observation helps in dealing with these situations. Thus, the aim and objective of our study was to study the maternal and fetal complications and to analyse perinatal mortality and morbidity associated with twin pregnancies in our institution.

\section{METHODS}

This study included prospective observational analysis of 50 women with twin pregnancies, over a period of 6 months from January 2021 to June 2021 in department of obstetrics and gynaecology, VMKVMCH, Salem.
Patients in this study were from different socio-economic status and had different educational status. Detailed history including family history, infertility treatment history was taken. All routine and specific investigations were done. They were hospitalized when required and complications were treated. Information pertaining to study like age, residence, parity, gravida, family history of twin pregnancy was obtained. Chorionicity was assessed using ultrasonogram antenatally and placental examination after delivery of the placenta. All the patients were delivered in our institution under close observation. Course of labour, mode of delivery and outcome of labour including fetal outcome were noted. Date, time of delivery, duration of labour and interval between the two babies were noted. All stages of labour were carefully managed with the presence of team of obstetricians. Antepartum, intra-partum and postpartum complications were also noted. All the babies were examined by neonatologist after birth and NICU care was given when required. Patients were followed-up till discharge.

\section{Statistical analysis}

Descriptive analysis of the baseline characteristics was analysed using mean, standard deviation (SD), percentages and proportions along with $95 \%$ confidence interval. Proportions were compared using Chi-square test of significance. $\mathrm{P}<0.05$ was accepted as indicating statistical significance. Data was analysed using Microsoft excel and SPSS V26.

\section{Inclusion criteria}

Women with twin pregnancy of more than 28 weeks of gestational age attending antenatal OP/ antenatal ward/ labour ward were included in the study.

\section{Exclusion criteria}

Patients with triplet pregnancy and higher order multifetal gestations, patients with gestational age less than 28 weeks, patients with known history of chronic hypertension/ diabetes mellitus/ chronic renal disease and other chronic medical disorders and one fetus delivered outside our hospital were excluded from the study.

\section{RESULTS}

It is a prospective observational study in which we observed over 50 twin gestations, all booked in our institution. By satisfying inclusion criteria the following results were observed. Higher incidences were noted between the age group of $20-25$ years $(76 \%), 18 \%$ noted between age group of 26-30 years and a lower incidence was noted in patients above 30 years $(6 \%)$. In our study highest incidence of twin pregnancies with regards to parity were among primigravida (64\%) and maximum were of spontaneous conception ( $80 \%)$, followed by conception from ovulation induction $(20 \%)$. None of them had family history of twins or history of the same. In our 
study $22(44 \%)$ had preterm deliveries and $16(32 \%)$ delivered after 36 weeks of gestation as shown in Table 1.

When coming to maternal complications we noted 18 women $(36 \%)$ with anaemia, $13(26 \%)$ with preeclampsia, however only 2 patients had eclampsia and $12 \%$ had preterm premature rupture of membrane (PPROM). Six patients had hypothyroidism, 4 patients had GDM and only 3 patients had Oligohydramnios. In our study 31 (62\%) had DCDA, 16 (32\%) had MCDA and 3 $(6 \%)$ had MCMA. Majority of the patients underwent caesarean section (LSCS)-54\% for indications like non vertex presentation in 17 patients $(34 \%)$, previous LSCS in 3 cases (6\%), fetal distress in 7 cases (14\%) and 23 patients delivered vaginally (46\%) as shown in Table 2 .

Majority of the twin had caesarean section either elective or emergency. Mode of delivery according to chorionicity was also noted. 20 cases with DCDA (52.6\%) and 7 cases with MCDA $(58.3 \%)$ underwent caesarean section. 18 cases with DCDA (47.4\%) and 5 cases with MCDA (41.6\%) delivered vaginally as shown in Table 3.

Out of 50 cases, 20 patients had intrapartum complications like PPH, malpresentation, cord prolapse, low lying placenta, placental abruption. In this 14 had malpresentation and 5 had PPH. These intrapartum complications were also categorised according to their chorionicity. Malpresentations were seen in $26.3 \%$ of DCDA and $33.3 \%$ of MCDA with $\mathrm{p}=0.47$. Both were not satistically significant as shown in Table 4.

Single fetal demise was seen in 3 cases $(7.9 \%)$, TTTS in 1 case $(8.3 \%)$, acardia twin in 1 case $(8.3 \%)$ and 1 case had congenital anomalies (2.6\%). These twin specific complications were noted according to their chorionicity. Discordant twin was seen in $7.9 \%$ of DCDA and $8.3 \%$ MCDA with $p=0.57$ (statistically insignificant). Single IUD in $7.9 \%$ of DCDA and none in MCDA with $\mathrm{p}=0.57$ (statistically insignificant) as shown in Table 5.

Table 1: Demographic profile.

\begin{tabular}{|c|c|c|}
\hline Characteristics & $\begin{array}{l}\text { Number of } \\
\text { patients }\end{array}$ & $\begin{array}{l}\text { Percentage } \\
(\%)\end{array}$ \\
\hline \multicolumn{3}{|c|}{ Maternal age (years) } \\
\hline $20-25$ & 38 & 76 \\
\hline $26-30$ & 9 & 18 \\
\hline$>30$ & 3 & 6 \\
\hline \multicolumn{3}{|l|}{ Parity } \\
\hline Primigravida & 32 & 64 \\
\hline Multigravida & 18 & 36 \\
\hline \multicolumn{3}{|l|}{ Mode of conception } \\
\hline Spontaneous & 40 & 80 \\
\hline Infertility treatment & 10 & 20 \\
\hline \multicolumn{3}{|c|}{ Gestational age (weeks) } \\
\hline $28-32$ & 22 & 44 \\
\hline$>32-36$ & 12 & 24 \\
\hline$>36$ & 16 & 32 \\
\hline
\end{tabular}

Table 2: Antenatal maternal complications and mode of delivery.

\begin{tabular}{|c|c|c|c|}
\hline \multicolumn{2}{|c|}{ Characteristics } & Number & $\begin{array}{l}\text { Percentage } \\
(\%)\end{array}$ \\
\hline \multicolumn{4}{|c|}{ Antenatal maternal complications } \\
\hline \multicolumn{2}{|c|}{ Preeclampsia } & 13 & 26 \\
\hline \multicolumn{2}{|c|}{ Eclampsia } & 2 & 4 \\
\hline \multicolumn{2}{|c|}{ Anaemia } & 18 & 36 \\
\hline \multicolumn{2}{|c|}{ Abruptio placenta } & 3 & 6 \\
\hline \multicolumn{2}{|c|}{ Oligohydramnios } & 3 & 6 \\
\hline \multicolumn{2}{|c|}{ GDM } & 4 & 8 \\
\hline \multicolumn{2}{|c|}{ Hypothyroidism } & 6 & 12 \\
\hline \multicolumn{2}{|c|}{$\begin{array}{l}\text { Premature rupture of } \\
\text { membrane }\end{array}$} & 4 & 8 \\
\hline \multicolumn{2}{|c|}{$\begin{array}{l}\text { Preterm premature } \\
\text { rupture of membrane }\end{array}$} & 6 & 12 \\
\hline \multicolumn{2}{|c|}{$\begin{array}{l}\text { Gestational } \\
\text { thrombocytopenia }\end{array}$} & 1 & 2 \\
\hline \multicolumn{4}{|c|}{ Mode of delivery } \\
\hline \multicolumn{2}{|c|}{ Normal vaginal delivery } & 23 & 46 \\
\hline \multirow{3}{*}{$\begin{array}{l}\text { Caesarean } \\
\text { section/ } \\
\text { LSCS } \\
(54 \%)\end{array}$} & Non-vertex & 17 & 34 \\
\hline & $\begin{array}{l}\text { Previous } \\
\text { LSCS }\end{array}$ & 3 & 6 \\
\hline & $\begin{array}{l}\text { Fetal } \\
\text { distress }\end{array}$ & 7 & 14 \\
\hline
\end{tabular}

Table 3: Mode of delivery depending on chorionicity.

\begin{tabular}{|llllll|}
\hline $\begin{array}{l}\text { Mode of } \\
\text { delivery }\end{array}$ & $\begin{array}{l}\text { Dichorionic } \\
\text { diamniotic, } \\
\text { (n=38) }\end{array}$ & $\begin{array}{l}\text { Monochorionic } \\
\text { N }\end{array}$ & $\begin{array}{l}\text { \% } \\
\text { diamniotic, } \\
(\mathbf{n = 1 2})\end{array}$ & $\begin{array}{l}\text { N } \\
\text { v }\end{array}$ \\
\hline $\begin{array}{l}\text { Normal } \\
\text { vaginal } \\
\text { delivery }\end{array}$ & 18 & 47.4 & 5 & 41.6 & 0.98 \\
\hline $\begin{array}{l}\text { Caesarean } \\
\text { /LSCS }\end{array}$ & 20 & 52.6 & 7 & 58.3 & 0.97 \\
\hline Total & 38 & 100 & 12 & 100 & \\
\hline
\end{tabular}

Table 4: Intrapartum complications according to the chorionicity.

\begin{tabular}{|c|c|c|c|c|c|}
\hline \multirow[t]{2}{*}{ Variables } & \multicolumn{2}{|c|}{$\begin{array}{l}\text { Dichorionic } \\
\text { diamniotic, } \\
(\mathbf{n}=\mathbf{3 8})\end{array}$} & \multicolumn{2}{|c|}{$\begin{array}{l}\text { Monochorionic } \\
\text { diamniotic, } \\
(\mathrm{n}=12)\end{array}$} & \multirow[t]{2}{*}{$\begin{array}{l}\mathbf{P} \\
\text { value }\end{array}$} \\
\hline & $\mathbf{N}$ & $\%$ & $\mathbf{N}$ & $\%$ & \\
\hline $\begin{array}{l}\text { Post- } \\
\text { partum } \\
\text { hemorrhage }\end{array}$ & 4 & 10.5 & 1 & 8.3 & 0.47 \\
\hline $\begin{array}{l}\text { Malpresent } \\
\text { ation }\end{array}$ & 10 & 26.3 & 4 & 33.3 & 0.72 \\
\hline $\begin{array}{l}\text { Cord } \\
\text { prolapses }\end{array}$ & 2 & 5.3 & 0 & 0 & 0.97 \\
\hline $\begin{array}{l}\text { Low lying } \\
\text { placenta }\end{array}$ & 1 & 2.6 & 0 & 0 & 0.54 \\
\hline $\begin{array}{l}\text { Placental } \\
\text { abruption }\end{array}$ & 2 & 5.3 & 0 & 0 & 0.97 \\
\hline Total & 19 & 50 & 5 & 41.6 & \\
\hline
\end{tabular}


Table 5: Twin specific fetal complications according to the chorionicity.

\begin{tabular}{|llllll|}
\hline Variables & $\begin{array}{l}\text { Dichorionic } \\
\text { diamniotic, } \\
(\mathbf{n = 3 8})\end{array}$ & $\begin{array}{l}\text { Monochorionic } \\
\text { N }\end{array}$ & $\begin{array}{l}\text { \% } \\
\text { diamniotic, } \\
(\mathbf{n = 1 2})\end{array}$ & $\mathbf{N}$ & $\begin{array}{l}\text { P } \\
\text { value }\end{array}$ \\
\hline $\begin{array}{l}\text { Twin to } \\
\text { twin } \\
\text { transfusion } \\
\text { syndrome }\end{array}$ & 0 & 0 & 1 & 8.3 & 0.24 \\
$\begin{array}{l}\text { Discordant } \\
\text { twins }\end{array}$ & 3 & 7.9 & 1 & 8.3 & 0.57 \\
$\begin{array}{l}\text { Acardiac } \\
\text { twins }\end{array}$ & 0 & 0 & 1 & 8.3 & 0.24 \\
\hline $\begin{array}{l}\text { Single } \\
\text { intrauterine } \\
\text { fetal demise }\end{array}$ & 3 & 7.9 & 0 & 0 & 0.57 \\
\hline $\begin{array}{l}\text { Congenital } \\
\text { anomalies }\end{array}$ & 1 & 2.6 & 0 & 0 & 0.54 \\
\hline Total & 7 & 18.4 & 3 & 25 & \\
\hline
\end{tabular}

Table 6: Neonatal weight, complications and the outcome.

\begin{tabular}{|c|c|c|}
\hline Variables & Twin 1 & Twin 2 \\
\hline \multicolumn{3}{|l|}{ Birth weight (kg) } \\
\hline$<1$ & 4 & 4 \\
\hline $1-1.5$ & 3 & 6 \\
\hline $1.5-2$ & 22 & 16 \\
\hline $2-2.5$ & 15 & 17 \\
\hline$>2.5$ & 6 & 7 \\
\hline NICU admission & Number & Percentage $(\%)$ \\
\hline Needed & 61 & 65.6 \\
\hline Not needed & 32 & 34.4 \\
\hline \multicolumn{3}{|c|}{ Perinatal mortality (cause) } \\
\hline Intrauterine death & 1 & 1.1 \\
\hline $\begin{array}{l}\text { Twin to twin } \\
\text { transfusion syndrome }\end{array}$ & 1 & 1.1 \\
\hline Birth asphyxia & 3 & 3.2 \\
\hline $\begin{array}{l}\text { Respiratory distress } \\
\text { syndrome }\end{array}$ & 2 & 2.2 \\
\hline \multicolumn{3}{|c|}{ Expired neonate and their chorionicty } \\
\hline $\begin{array}{l}\text { Dichorionic } \\
\text { diamniotic, }(n=38)\end{array}$ & 4 & 10.5 \\
\hline $\begin{array}{l}\text { Monochorionic } \\
\text { diamniotic, }(n=12)\end{array}$ & 3 & 25 \\
\hline
\end{tabular}

Out of 100 babies, 70 weighed between $1.5-2.5 \mathrm{~kg}$ (70\%), 8 had extremely low birth weight and $<20 \%$ had discordance in weight between twins. In our study prematurity was a major problem and incidence of perinatal mortality $7.5 \%$. Out of 7 perinatal mortalities, one was IUD, 2 were due to respiratory distress syndrome and 3 were due to birth asphyxia. These neonatal deaths were also noted based on their chorionicity. Out of 7 neonatal deaths, 4 were from DCDA and the 3 from MCDA. $P=0.34$ (statistically insignificant) as shown in the Table 6.

\section{DISCUSSION}

Multifetal gestation is a high-risk pregnancy as it has antepartum, intrapartum as well as fetal complications, including long term developmental issues. In last 2 decades, assisted reproductive technologies have seen a greater number of multiple gestations. Studies conducted in India since 1970s showed maternal twinning rate at 9$16 / 1000$ births. $^{13}$

In our study $80 \%$ had spontaneous conception and $20 \%$ conceived from ovulation induction. Our findings shows that maternal and perinatal morbidity and mortality among twin births were in low resource setting and twin pregnancy poses an intrinsic risk to both mother and neonates.

We observed the highest incidence in the age group of 20$25(76 \%)$ and least incidence was noted in women above 30 years $(6 \%)$. Highest incidence was noted among primigravida.

All participants were registered, had regular antenatal check-up in our institution and underwent adequate ultrasounds. In spite of this good antenatal care $68 \%$ had preterm delivery in our study, whereas Chowdhury et al showed 44\%, Hashimoto et al and other series showed 29$54 \%$. Bangal et al showed $88 \%$ preterm delivery which was much higher than our study. ${ }^{14,15}$

Our study showed that, common antepartum complications associated with twin pregnancy were anaemia (36\%), pre-eclampsia $(26 \%)$ and preterm deliveries $(68 \%)$ but study conducted by Rizwan et al showed preterm labour (84\%), anaemia (65.6\%) and hypertension $(31.2 \%)$ as common antepartum complications which is much higher than our study. ${ }^{16}$ Spellacy et al study showed $9.4 \%$ and Chowdhury et al showed $26 \%$ of anaemia in their study. Generally, incidence of pre-eclampsia is 2.6 times higher in twin gestation than in singleton pregnancy. ${ }^{17}$ Spellacy et al study showed $12 \%$ of pre-eclampsia whereas in this study we noted higher rate of $26 \%$.

In our study $54 \%$ had caesarean section which was like Chittacharoen study. ${ }^{18,19}$ Average birth weight ranges between $1.5-2.5 \mathrm{~kg}$ in both the twins as supported by Chowdhury et al study and Bangal et al showed incidence of $1.5-2.5 \mathrm{~kg}$ birth weight in $82 \%$. No maternal mortality was noted in our study. NICU admissions were required in $65.6 \%$ of cases. Our study showed 7 perinatal deaths (7.6\%), which was like Adesina et al study and Sulthan et al reported $11 \%$ of perinatal mortality.

\section{CONCLUSION}

Twin pregnancy seems to be a significant risk factor for maternal and perinatal mortality and morbidity. Even though management of twin pregnancy is challenging, most of the complications are preventable. Proper 
antenatal care with timely decisions can lead to better fetomaternal outcome and a better antenatal care proved to be an important factor in lowering the incidence of perinatal mortality.

Funding: No funding sources Conflict of interest: None declared

Ethical approval: The study was approved by the Institutional Ethics Committee

\section{REFERENCES}

1. Mathew R, Wills V, Abraham J. Maternal determinants and fetal outcome of twin pregnancy: a five-year survey. Int J Reprod Contracept Obstet Gynecol. 2017;6:2459-65.

2. Jahanfar S, Lim K. Adverse maternal outcomes and birth weight discordance in twin gestation: British Columbia, Canadian data. Int $\mathrm{J}$ Womens Health. 2017;9:871-8.

3. Santana DS, Silveira C, Costa ML. Perinatal outcomes in twin pregnancies complicated by maternal morbidity: evidence from the WHO Multicounty Survey on Maternal and Newborn Health. BMC Pregnancy Childbirth. 2018;18:449.

4. Jones HW. Multiple births: How are we doing? Fertility sterility. 2003;79(1):17-21.

5. Bangal VB, Patel SM, Khairnar DN. Study of Maternal and Fetal Outcome In Twin Gestation At Tertiary Care Teaching Hospital. Int J Biomed Adv Res. 2012;3(10):758-62.

6. Blondel B, Kaminski M. Trends in the occurrence, determinants, and consequences of multiple births. Semin Perinatol. 2002;26(4):239-49.

7. Jewell SE, Yip R. Increasing trends in plural births in the United States. Obstet Gynecol. 1995;85(2):22932.

8. Lee YJ, Kim MN, Kim YM, Sung JH, Choi SJ, Oh SY et al. Perinatal outcome of twin pregnancies according to maternal age. Obstet Gynecol Sci. 2019;62(2):93102.

9. Jhaveri RR, Nadkarni TK. Perinatal Outcome of Second Twin with Respect to Mode of Delivery: An Observational Study. J Clin Diagn Res.
2016;10(12):QC26-8.

10. Gardosi J. Toward safe standards for assessment of fetal growth in twin pregnancy. Am J Obstet Gynecol. 2017;216(5):431-3.

11. Ma D, Szeto IM, Yu K, Ning Y, Li W, Wang J et al. Association between gestational weight gain according to prepregnancy body mass index and short postpartum weight retention in postpartum women. Clin Nutr. 2015;34(2):291-5.

12. Kumari, Misra K, Jhanwar M, Kumari A, Asha. Fetomaternal Outcome in Twin Pregnancies: A Retrospective Analysis from a Tertiary Care Centre. J clin diagnostic res. 2020;14:10.

13. Smits J, Monden C. Twinning across the Developing World. PLoS ONE. 2011;6(9):e25239.

14. Chowdhury S, Hussain MA. Maternal complications in twin pregnancies. Mymensingh Med J. 2011;20(1):83-7.

15. Bangal VB, Patel SM, Khairnar DN. Study of maternal and foetal outcome in twin gestation at tertiary care teaching hospital. IJBAR. 2012;3(10):758.

16. Rizwan N, Abbasi RM, Mughal R. Maternal morbidity and perinatal outcome with twin pregnancy. J Ayub Med Coll Abbottabad. 2010;22(2):105-7.

17. American College of Obstetricians and Gynecologists Committee on Practice Bulletins-Obstetrics; Society for Maternal-Fetal Medicine; ACOG Joint Editorial Committee. ACOG Practice Bulletin \#56: Multiple gestation: complicated twin, triplet, and high-order multifetal pregnancy. Obstet Gynecol. 2004;104(4):869-83.

18. Chittacharoen A, Singhakun D, Ayudhya NI. Pregnancy outcome of twin pregnancy in Ramathibodi Hospital. J Med Assoc Thai. 2006;89(4):S76-80.

19. Qazi G. Obstetric and perinatal outcome of multiple pregnancy. J Coll Physicians Surg Pak. $2011 ; 21(3): 142-5$

Cite this article as: Sundaram S, Govindaraj K. Fetomaternal outcome in multiple pregnancy. Int J Reprod Contracept Obstet Gynecol 2021;10:4407-11. 